\title{
Growth Performance of the Mangrove Oyster Cultivated on the Amazon Coast
}

\author{
Rafael Anaisce das Chagas ${ }^{1 *}$ \\ http://orcid.org/0000-0002-1555-6154
}

Mara Rúbia Ferreira Barros ${ }^{1}$

http://orcid.org/0000-0003-1354-7550

Valdo Sena de Abreu ${ }^{2}$

http://orcid.org/0000-0001-8838-7841

\author{
Matheus Silva de Almeida ${ }^{2}$ \\ https://orcid.org/0000-0003-0431-3226
}

Wagner César Rosa dos Santos ${ }^{2}$

http://orcid.org/0000-0001-8172-9917

Marko Herrmann ${ }^{2}$

http://orcid.org/0000-0001-9891-6700

Rosana Esther Oliveira da Silva ${ }^{2}$

https://orcid.org/0000-0001-6431-5042

${ }^{1}$ Federal University of Pará, Institute of Biological Sciences, Belém, Pará, Brazil; 2 Federal Rural University of the Amazon, Belém, Pará, Brazil

Editor-in-Chief: Paulo Vitor Farago

Associate Editor: Camila Fediuk de Castro Guedes

Received: 2019.10.28; Accepted: 2020.09.10.

*Correspondence: rafaelanaisce@hotmail.com or rafaelanaisce@gmail.com; Tel.: (+5591) 984809124 (R.A.C.).

\section{HIGHLIGHTS}

- Total and percentage growth rates, higher performance was observed in the oysters classified by juvenile and seed, respectively.

- The relationship of salinity to oyster growth was evidenced only in the class of juvenile oysters.

- The cultivation time required to obtain native oysters in the commercial size varied between four and seven months.

\begin{abstract}
In the last decades the oyster faming stands out as the main mitigating measure to the decline of the fishery, as it presents socio-economic and environmental viability. However, for the success of the activity, it is necessary to understand the stages of cultivation, as well as the growth performance of the species to be cultivated. The present work aims to characterize the growth and survival of Crassostrea tulipa, cultivated on the Amazon coast. For this purpose, oysters were grouped by commercial size class (seed, juvenile, baby, average and masters) and compared the growth rates and their relationships with the abiotic variables. There was no difference in the average growth between the oyster classes, however, when comparing them in the total and percentage growth rates, a higher performance was observed in the oysters classified by juvenile and seed, respectively. The relationship of salinity to oyster growth was evidenced only in the class of juvenile oysters. The cultivation time required to obtain native oysters in the commercial size varied between four and seven months, being inferior to those found in other Brazilian regions.
\end{abstract}


Keywords: Amazon region; aquaculture; mollusk; oyster farming; native oyster; Crassostrea tulipa.

\section{INTRODUCTION}

World production from bivalve mollusk aquaculture plays an important role in human nutrition, and from the 1980s onwards it has grown rapidly until 2014 [1]. This growth in bivalve production is a result, for example, of the success of mussel farming and oyster farming, which appears as a viable alternative to mitigate fishery decline, reducing pressure on natural stocks [2] and becoming a source of income for coastal communities [3-5].

In Brazil, oyster faming is restricted to the cultivation of four oysters of the genus Crassostrea Sacco, 1897: the native oysters Crassostrea tulipa (Lamarck, 1819) (sin. Crassostrea gasar (Deshayes, 1830)), Crassostrea rhizophorae (Guilding, 1828), Crassostrea brasiliana (Lamarck, 1819) and the exotic oyster Crassostrea gigas (Thunberg, 1793) [6,7]. However, Brazil is only a producer of Crassostrea sp. oysters because of the taxonomical instability of oysters grown [see 8 and their references].

There are oyster crops throughout the Brazilian coast, however in the North and Northeast regions they are handmade and, in the South and Southeast, industrially [9]. In this scenario, the State of Santa Catarina stands out [2, 10], responsible for $97.9 \%$ of Brazilian production in 2016 [11]. In the same year, oyster faming in the State of Pará presented a productivity of $\sim 42$ tons, $(0.2 \%$ of the national production) [11].

Success in oyster farming depends heavily on the environmental conditions of the growing area, that is the physical, chemical and biological characteristics of the environment [4,7,10,12-19]. These factors directly influence the growth of the cultivated oyster, and because of this, several studies have been carried out $[6,12,15,18,20-26]$.

In this sense, the present work aims to characterize the growth of the $C$. tulipa mangrove oyster, cultivated in the Amazon coast, and compare it with the performance of oysters grown on the Brazilian coast.

\section{MATERIAL AND METHODS}

The study site is located in the estuarine zone of the Urindeua river basin, Salinópolis Municipality, State of Pará, Northern Brazil (Figure 1). In "Associação dos Agricultores, Pecuaristas e Aquicultores - ASAPAQ" of the Vila de Santo Antônio de Urindeua the cultivate the oyster $C$. tulipa, buying the seed at the "Associação de Aquicultores de Vila de Lauro Sodré - AQUAVILA", located in the Municipality of Curuçá [5,9]. According to the authors, the cultivation system used in ASAPAQ is of the fixed table type, using pillows and lanterns. According to oyster farmers, the lanterns are replaced by pillows and bags, mainly because of the amount of predators (e.g., Stramonita brasiliensis) [7]. 

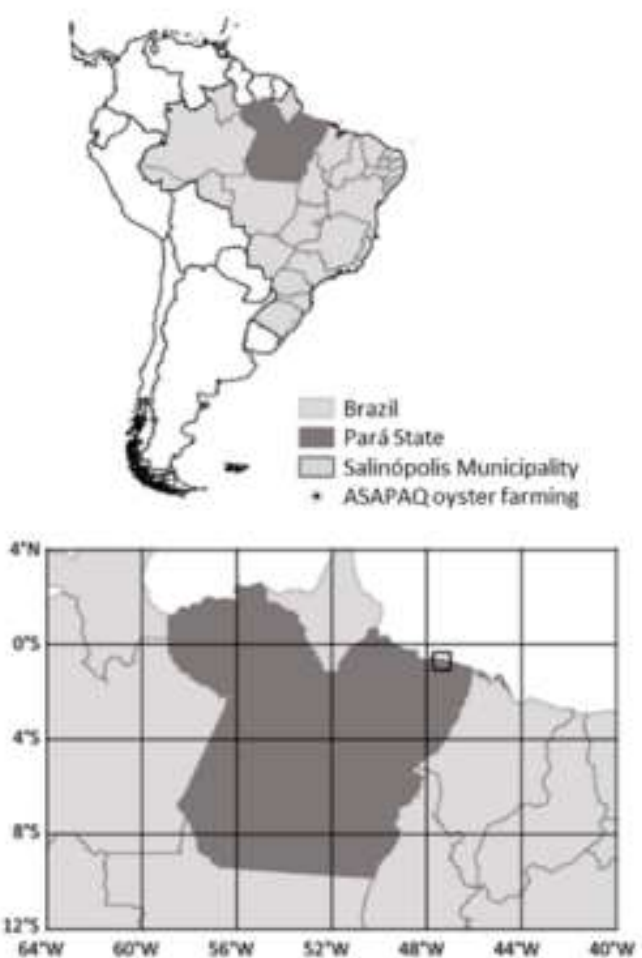

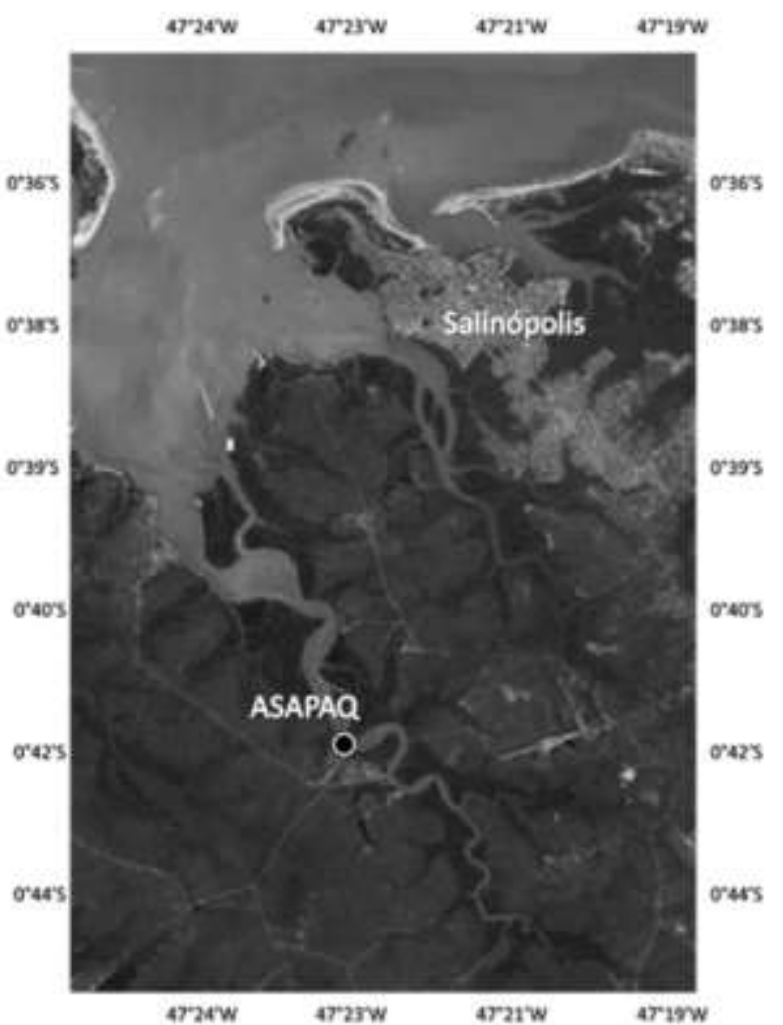

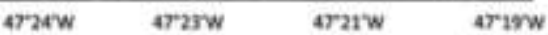

Figure 1. Location of the oyster farms of the Association of Farmers, Pecuaristas and Aquicultores - ASAPAQ, located in the Urindeua river, Amazon coast.

In April 2016, for this growth study in oyster $C$. tulipa cultivated was used 600 oyster of ASAPAQ that was arranged in four lanterns and distributed in commercial size classes (seed: 15 to $29 \mathrm{~mm}$ long, juvenile: 30 to $59 \mathrm{~mm}$, baby: 60 to $79 \mathrm{~mm}$, average: 80 to $100 \mathrm{~mm}$, and master:> $100 \mathrm{~mm}$ ). In the sampling the oyster shells were cleaned, according to Chagas [7], and the total shell length was measured according to Quayle [27], using a digital caliper (mark: TESA - Datadirect, accuracy: $0.01 \mathrm{~mm}$ ).

For characterization of $C$. tulipa growth, the morphometric data were previously grouped by size classes. From this, the average monthly growth $\left(T_{c m}\right)$ and total $\left(T_{c t}\right)$ were estimated according to Equation 1 and 2 below:

$$
\begin{gathered}
T_{c m}=\frac{\sum\left(C_{m t}-C_{m i}\right)}{N_{\text {oyster }}} \\
T_{c t}=\frac{C_{m f}-C_{m i}}{N_{\text {months }}}
\end{gathered}
$$

Where, $T_{c m}$ is the average monthly growth rate, $C_{m t}$ is the total length of each oyster measured in the current month, $C_{m i}$ is the average of the total length of the oysters at the beginning of the experiment. $T_{c t}$ represents the average rate of total oyster growth at the end of the experiment, $C_{m f}$ is the mean total length of the oysters measured in the last month and $N_{\text {months }}$ the number of months of the experiment.

The survival rate of $C$. tulipa was estimated by size classes through Equation 3 below:

$$
S=\frac{N_{t}}{N_{0}} \cdot 100
$$

Where, $S$ is the percentage survival of oysters at the end of the experiment, $N_{t}$ is the number of surviving individuals and $N_{0}$ is the initial number of individuals in the experiment.

The Shapiro-Wilk test $(p<0.05)$ was applied to verify the normality of the data. Then, in order to compare the $T_{c m}$ obtained from each class of total oyster length at the end of the study, the analysis of variance (ANOVA one-way) was performed. When differences between the $T_{c m}$, were found, the means were compared through the Tukey test, at a significance level of $5 \%$.

It was verified the correlation between the abiotic variables (salinity and TSA) and the classes of cultivated oyster. For this, simple regressions were performed between the variables (through Equation 2 ), with the 
dependent variable $(\mathrm{Y})$ corresponding to the $T_{c m}$ per class of oysters and the independent variable $(\mathrm{X})$ being the abiotic factors. The data were log transformed with the intention of reducing the amplitude of variation among the correlated variables. Pearson's correlation coefficients ( $r$ ) were classified according to the classification proposed by Hopkins [28].

All statistical analyzes were considered at a significance level of $95 \%(\alpha=0.05)$ [29], using the software PAST - PAlaeontological STatistics (Version 4.0) [30].

At the same time, the abiotic data (salinity and TSA) were measured during the ebb tide in each month, using a manual refractometer and a digital immersion thermometer, respectively. The rainfall data were obtained from the website of the National Water Agency (http://www3.ana.gov.br/).

\section{RESULTS AND DISCUSSION}

Variability in abiotic data is observed throughout the collection months. The highest variation was observed in the salinity, with a mean of $22.5 \pm 12.6$ (mean $\pm S D)$, minimum value of $3(\mathrm{Apr} / 16)$ and maximum of $39(\mathrm{Nov} / 16)$. The temperature presented little variation, with $31.2 \pm 0.9^{\circ} \mathrm{C}$, minimum of $30.1^{\circ} \mathrm{C}(\mathrm{Jul} / 16)$ and maximum of $33.7^{\circ} \mathrm{C}($ April/16). The average monthly rainfall was inversely proportional to salinity, with a mean of $5.8 \pm 7.3 \mathrm{~mm}_{\text {.day }}{ }^{-1}$, presenting months with no rainfall (Set/16 and Oct/16) and maximum of $20.59 \mathrm{~mm}$. $\operatorname{day}^{-1}(\mathrm{Apr} / 17)$ (Figure 2).

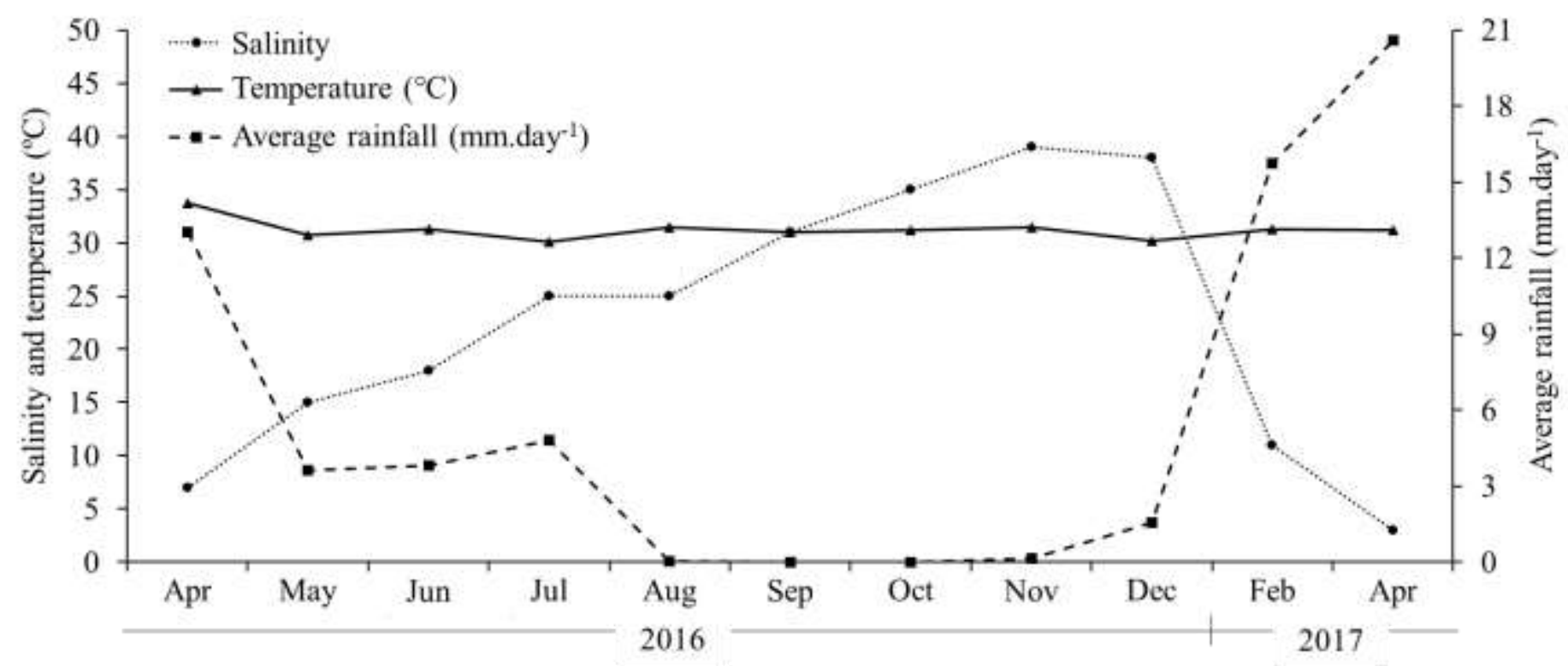

Figure 2. Variation of salinity and surface water temperature (TSA) during spring tides and monthly average rainfall in ASAPAQ oysters in the Urindeua river, Salinópolis, Pará, between 2016/April and 2017/April.

The temperature is a variable that depends on the time of collection and the seasonal season, however the average surface temperature of the water found in the Urindeua river is in agreement with other rivers in the Amazon [31]. The salinity rise and rainfall decline is related to the beginning of the less rainy season (dry season), delimited by the authors between June and November.

The monthly morphometric data of $C$. tulipa are available in Chagas [32], on the Data Publisher for Earth \& Environmental Science - PANGAEA (https://www.pangaea.de/) platform. From these data, oyster growth was observed in all commercial classes, by means of the monthly average lengths measured (Figure 3 ) and the percentage of growth over the sampled period (Figure 4). Greater performance in the growth of oysters classified by seeds (116\%) in the study period. 


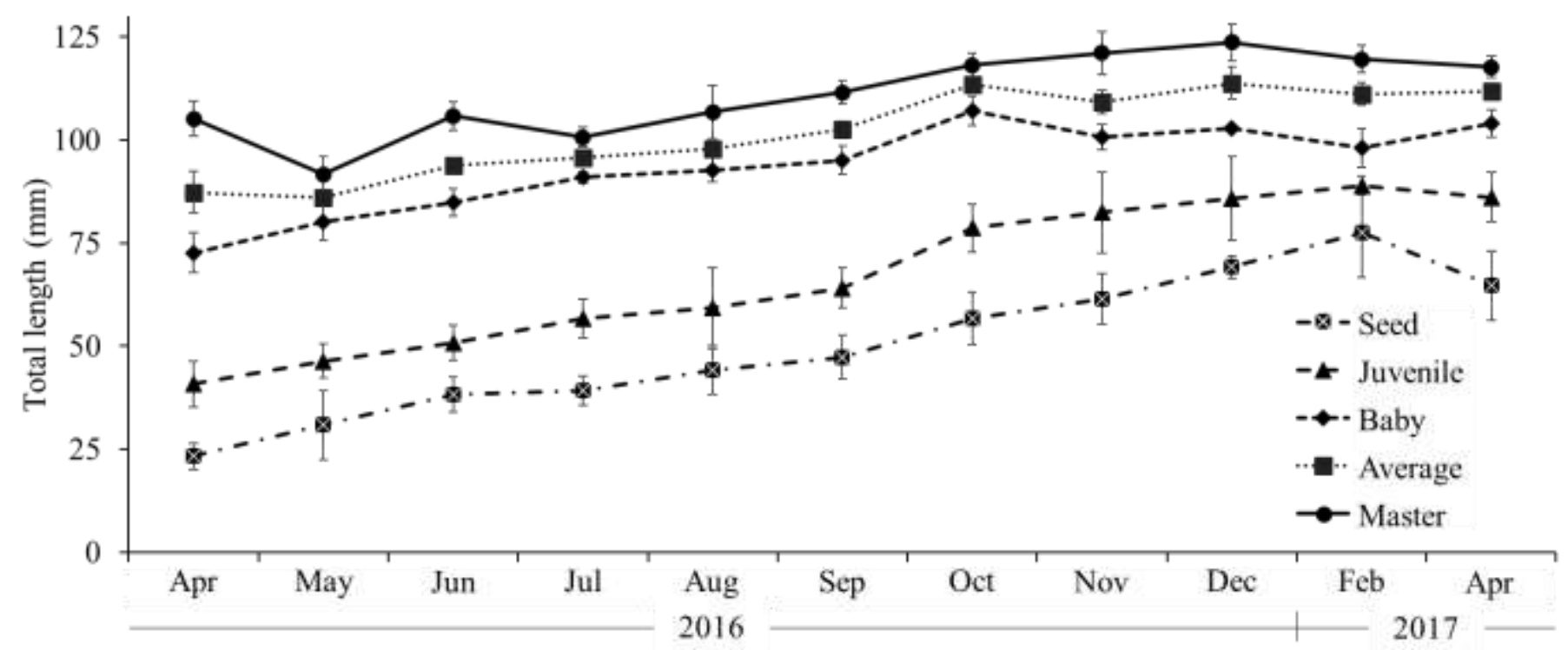

Figure 3. Mean values of total length of oysters collected monthly in ASAPAQ cultivation in the Urindeua river, Salinópolis, Pará, between April/2016 and April/2017. Error bars (upper and lower) represent the standard deviation of the measured total length averages.

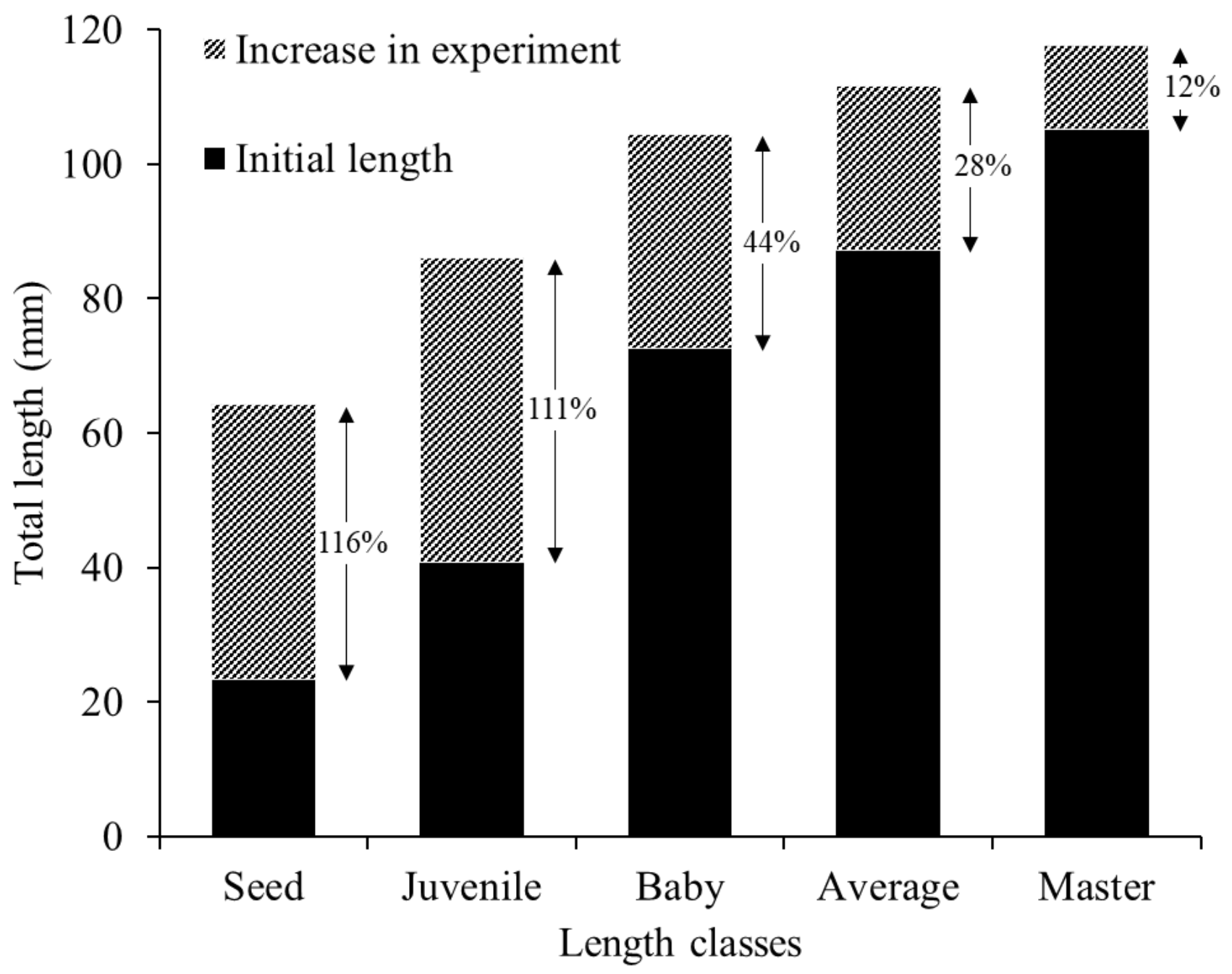

Figure 4. Percentage growth of oysters during the experiment. 
According to the review prepared by Chagas and Herrmann [33], it is observed that $46 \%$ of the studies present the juvenile class as minimum size at the beginning of the experiment, $32 \%$ with pre-seed, $12 \%$ with seed and $10 \%$ with baby. Studies that address oyster growth performance in the Brazilian coast compare the average monthly growth without distinction of classes [6,22], which leads to biased or misleading comparisons. As a result, at the standardization level, the performance of oysters grown with studies using equivalent grades was compared.

The commercial size of the oyster is related to the form of consumption, the species and the regional preference [6]. C. tulipa presents $60 \mathrm{~mm}$ as initial commercial size in the State of Pará [5, 9] and in this study, the oysters classified by seed and juveniles, took, on average, seven and four months, respectively, to reach commercial size (Figure 3).

The oysters classified by seeds presented $T_{c m}=5.17 \pm 1.42 \mathrm{~mm}$ (mean $\pm \mathrm{SD}$ ), varying between 3.07 and $7.63 \mathrm{~mm}$, juveniles with $T_{c m}=5.03 \pm 0.88 \mathrm{~mm}$, varying between 3.61 and $6.46 \mathrm{~mm}$, baby with $T_{c m}=4.19 \pm 1.64 \mathrm{~mm}$, varying between 2.01 and $7.42 \mathrm{~mm}$, average with $T_{c m}=4.08 \pm 1.80 \mathrm{~mm}$, varying between 1.40 and $7.94 \mathrm{~mm}$, and master with $T_{c m}=6.22 \pm 4.10 \mathrm{~mm}$, varying between 2.36 and $14.12 \mathrm{~mm}$.

In the first three months of the experiment, there was a greater oscillation in the $T_{c m}$ of the oysters, with emphasis on the oyster masters that showed a sharp decrease in $T_{c m}$ between the months of June and July 2016. The considerable range of $T_{c m}$ of the average oysters between May and June of the same year is highlighted. After July 2016, a balance was observed in the $T_{c m}$ of the oysters, with small variations in the following months. It is noteworthy that juvenile oysters presented the smallest variation $T_{c m}$ in the experiment period (Figure 5).

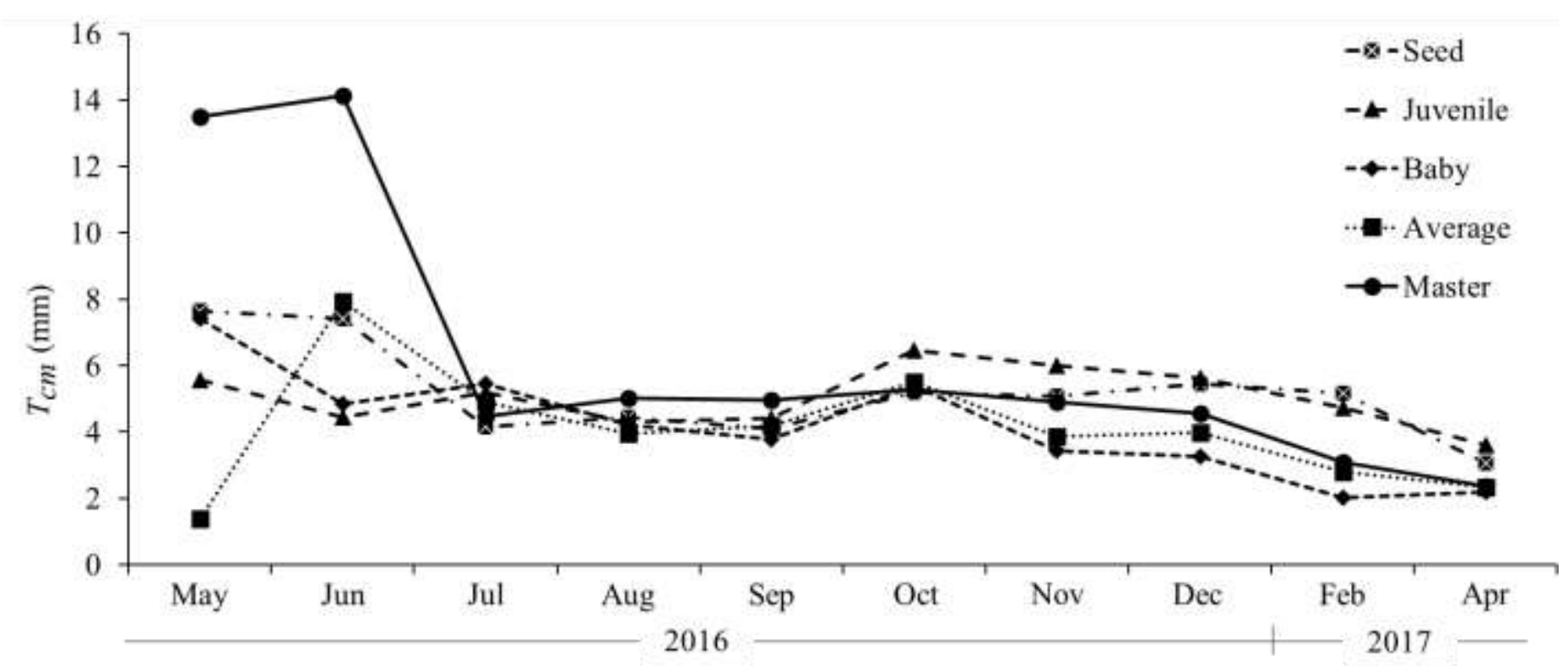

Figure 5. Variation of the average monthly growth rates $\left(T_{c m}\right)$ in the respective oyster length classes: seed, juvenile, baby, average and master.

According to the ANOVA result, no evidence of significant differences was found $\left(F_{c}=1.464<F_{t}=2.578\right.$; $p=0.22$ ), accepting the null hypothesis. Therefore, the values of $T_{c m}$ obtained in each class of total length of the oysters at the end of the study do not present differences (Figure 6). This result was also perpetuated in the Tukey test, with no significant differences. 


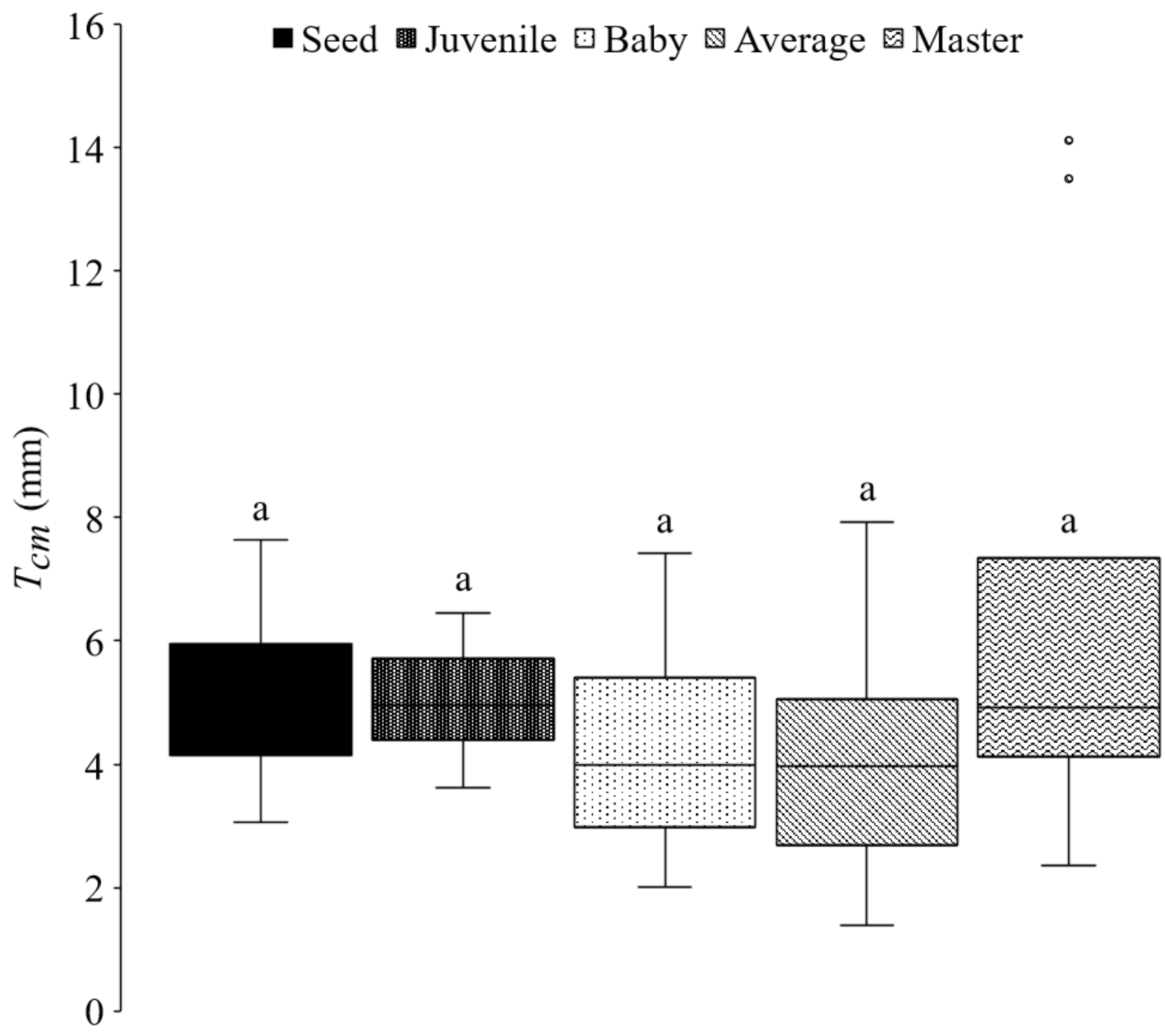

Figure 6. Average monthly growth rates $\left(T_{c m}\right)$ in oyster length classes. Equal letters indicate statistical equality at a significance level of $5 \%$.

According to the classification proposed by Hopkins [28], from the Pearson correlation coefficient ( $r$ ), they indicate a low correlation between the $T_{c m}$ of the oyster classes and the monthly TSA (Table 1). When analyzing the $T_{c m}$ of the oysters and the monthly variation of salinity, a correlation classified as "moderate" between the abiotic variable and the seed, baby, average and master classes is verified. The relationship between the juvenile class and the salinity is highlighted, classifying the correlation as "very high" (Table 1). This higher performance of juvenile oysters is evident in Figure 5, where in the months with the highest salinities (October, November and December 2016), the $T_{c m}$ of this class was higher than the others.

Table 1. Pearson correlation coefficients $(r)$ obtained from the correlations between the size of oysters marketed and the abiotic variables (salinity and TSA) monthly, classifying them in: $a=$ very low, $b=$ low, $c=$ moderate and $d=$ very high.

\begin{tabular}{lcc}
\hline Oyster classes & Salinity & TSA $\left({ }^{\circ} \mathbf{C}\right)$ \\
\hline Seed & $0.35^{c}(p=0.31)$ & $0.03^{\mathrm{a}}(p=0.92)$ \\
Juvenile & $0.71^{\mathrm{d}}(p=0.02)$ & $0.24^{\mathrm{b}}(p=0.47)$ \\
Baby & $0.46^{\mathrm{c}}(p=0.17)$ & $0.28^{\mathrm{b}}(p=0.40)$ \\
Average & $0.49^{\mathrm{c}}(p=0.14)$ & $0.07^{\mathrm{a}}(p=0.83)$ \\
Master & $0.35^{\mathrm{c}}(p=0.31)$ & $0.03^{\mathrm{a}}(p=0.91)$ \\
\hline
\end{tabular}


Legat [6] reported that $C$. tulipa oysters presented better growth performance in Santa Catarina, when compared to those grown in the State of Maranhão. However, the growth performance found in this study is well above those found by other authors in the South and Southeast regions (Table 3).

In the Brazilian coastal studies, the oysters classified by pre-seeds had a mean growth rate $\left(T_{c t}\right)$ of $6.08 \pm 2.65 \mathrm{~mm}$ (mean $\pm \mathrm{SD}$ ), ranging from 2.53 to $9.96 \mathrm{~mm}$. When comparing the performance of those classified by seeds, it is observed that the average $T_{c t}$ found in this study $\left(T_{c l}=3.41 \mathrm{~mm}\right)$ was well below the national average $\left(T_{c i}=5.19 \pm 2.74 \mathrm{~mm}\right)$. This result is similar to that found by Pereira and Chagas Soares [34], in his experiment with $C$. brasiliana. A very different result was found when comparing the performance of juveniles and baby, who presented $T_{c t}$ well above the average found in other regions $\left(T_{c t}=2.95 \pm 2.24 \mathrm{~mm}\right.$ and $T_{c t}=0.16 \pm 0.03 \mathrm{~mm}$, respectively). The absence of experiments regarding the growth of average and master oysters and the high number of publications concerning pre-seeds and juveniles, occurs for different reasons. In the case of oysters classified by pre-seeds, it is important to understand their initial development, as well as their relation to environmental parameters. The juveniles, however, represent the most commercialized oyster lengths in Brazil, and because of this, the largest studies are aimed at these length classes.

Survival rates of oysters were high, with oysters classified as baby with a better percentage of survival $(\sim 85 \%)$ and masters with the lowest percentage ( 66\%) (Table 2). The survival rates of $C$. tulipa observed in the experiment period (Table 2) are considered optimal for man-oyster cultivation. The data obtained in other studies with the same cultivation period corroborate this assertion Legat [6] observed a superior survival rate (> 87\% and $91 \%$, respectively) to that found in this study (between 66 and $85 \%$ ) in their experiment with $C$. tulipa, in the states of Maranhão and Santa Catarina. Oliveira [35] has survived between 73 and $80 \%$ of the C. brasiliana oyster and between 87 and $94 \%$ of $C$. rhizophorae, both cultivated in the state of Bahia. However, using the same culture period, other studies have a low survival, such as 30\% [34] and 50\% [36], both using the C. brasiliana oyster in the state of São Paulo, and survival of $40 \%$ found in C. gigas culture in Santa Catarina [13].

On the other hand, some studies, using a shorter cultivation period, present a high survival rate of Crassostrea oysters on the Brazilian coast. Among these studies, we highlight 90\% survival, in ten months of cultivation of $C$. brasiliana, in São Paulo [20], 88\% in four months of cultivation in Paraná [14] and 93\% in five months of cultivation in Santa Catarina [10], both using Crassostrea sp. in their experiments. 
Table 2. Performance of oysters of the genus Crassostrea in different crops in the Brazilian coast, presenting values of initial length $\left(C_{0}\right)$, final length $\left(C_{f}\right)$, growing period $(T)$ in the month, average monthly growth rate $\left(T_{c t}\right)$ and percentage survival (S). Legend: Oysters sorted by semente (a), juvenile (b), baby (c), average (d) e master (e). Updated taxonomy of Crassostrea gasar $\left({ }^{*}\right)$ and values not available $\left(^{* *}\right)$. Source: Chagas and Herrmann [33].

\begin{tabular}{|c|c|c|c|c|c|c|c|}
\hline Species & $\mathrm{C}_{0}(\mathrm{~mm})$ & $C_{f}(\mathrm{~mm})$ & $\mathrm{T}$ & $T_{c t}(\mathrm{~mm} /$ month $)$ & $\mathbf{S}_{\%}$ & E & Source \\
\hline C. tulipa ${ }^{\mathrm{a}}$ & $23.3 \pm 3,1$ & $64.2 \pm 8.3$ & 12 & 3.4 & $\sim 74$ & PA & Present study \\
\hline C. tulipa b & $40.7 \pm 5,5$ & $86.0 \pm 5.9$ & 12 & 3.7 & $\sim 76$ & PA & Present study \\
\hline C. tulipa ${ }^{\mathrm{c}}$ & $72.5 \pm 4,8$ & $104.4 \pm 3.3$ & 12 & 2.6 & $\sim 85$ & PA & Present study \\
\hline C. tulipa d & $87.2 \pm 5,0$ & $111.7 \pm 1.9$ & 12 & 2.0 & $\sim 79$ & PA & Present study \\
\hline C. tulipa ${ }^{\mathrm{e}}$ & $105.1 \pm 4,2$ & $117.6 \pm 2.6$ & 12 & 1.0 & $\sim 66$ & PA & Present study \\
\hline C. tulipa* & $13.7 \pm 5,5$ & $49.6 \pm 7.3$ & 11 & ** & $\star \star$ & SC & [24] \\
\hline C. tulipa* & $9.6 \pm 5,4$ & $61.9 \pm 13.0$ & 11 & ** & ** & SC & [24] \\
\hline C. tulipa* & $5.8 \pm 2,0$ & $71.9 \pm 8.0$ & 13 & & $\sim 93$ & SC & [6] \\
\hline C. tulipa* & $5.8 \pm 2,0$ & $55.3 \pm 6.0$ & 13 & & $\sim 91$ & SC & [6] \\
\hline C. tulipa* & $5.8 \pm 2,0$ & $46.9 \pm 9.1$ & 13 & & $\sim 95$ & MA & [6] \\
\hline C. tulipa* & $5.8 \pm 2,0$ & $30.9 \pm 10.7$ & 13 & & $\sim 87$ & MA & [6] \\
\hline C. tulipa** & $40.8 \pm 8,7$ & $50.3 \pm 8.7$ & 4 & 2.37 & 67 & SE & [22] \\
\hline C. brasiliana & 32.2 & 60.5 & 12 & 2.36 & $\sim 50$ & SP & [36] \\
\hline C. brasiliana & $5.6 \pm 0,06$ & $25.8 \pm 0.3$ & 8 & & & SP & [15] \\
\hline C. brasiliana & 19.8 & 59.1 & 12 & 3.3 & $\sim 30$ & SP & [34] \\
\hline C. brasiliana & $\sim 50$ & 81.8 & 10 & 2.64 & $\sim 90$ & SP & [20] \\
\hline C. brasiliana & $\sim 50$ & 76.8 & 10 & 2.16 & $\sim 90$ & SP & [20] \\
\hline C. brasiliana & $\sim 50$ & 74.1 & 9 & 2.18 & 64 & SP & [20] \\
\hline C. brasiliana & $\sim 40$ & 55.8 & 12 & 1.75 & $\sim 87$ & BA & [35] \\
\hline C. brasiliana & $\sim 40$ & 60.8 & 12 & 2.65 & $\sim 91$ & BA & [35] \\
\hline C. brasiliana & $\sim 40$ & 53.3 & 12 & 1.58 & $\sim 87$ & BA & [35] \\
\hline C. brasiliana & $\sim 40$ & 55.6 & 12 & 2.28 & $\sim 94$ & $\mathrm{BA}$ & [35] \\
\hline C. gigas & $9.1 \pm 2.5$ & $82.8 \pm 8.5$ & 12 & ** & 40 & SC & [13] \\
\hline C. rhizophorae & $\sim 40$ & 53.3 & 12 & 1.48 & $\sim 73$ & BA & [35] \\
\hline C. rhizophorae & $\sim 40$ & 53.1 & 12 & 1.51 & $\sim 74$ & $\mathrm{BA}$ & [35] \\
\hline C. rhizophorae & $\sim 40$ & 46.5 & 12 & 1.29 & $\sim 80$ & BA & [35] \\
\hline C. rhizophorae & $\sim 40$ & 44.0 & 12 & 1.08 & $\sim 75$ & BA & [35] \\
\hline C. rhizophorae & 9 & $54.1 \pm 7.4$ & 5 & 9.9 & $* *$ & SC & [37] \\
\hline C. rhizophorae & 9 & $55.8 \pm 7.4$ & 5 & 10.2 & ** & SC & [37] \\
\hline C. rhizophorae & 9 & $49.8 \pm 6.9$ & 5 & 9 & ** & SC & [37] \\
\hline C. rhizophorae & 9 & $58.8 \pm 8.5$ & 5 & 10.8 & ** & SC & [37] \\
\hline C. rhizophorae & $6.2 \pm 1.0$ & $37.6 \pm 8.0$ & 10 & 3.1 & 45 & ES & [16] \\
\hline C. rhizophorae & 42.4 & $55.5 \pm 5.8$ & 3 & 4.3 & $\sim 45$ & CE & [38] \\
\hline C. rhizophorae & 42.4 & $55.7 \pm 4.2$ & 3 & 4.4 & $\sim 28$ & CE & [38] \\
\hline C. rhizophorae & 42.4 & $55.7 \pm 6.3$ & 3 & 4.4 & $\sim 17$ & CE & [38] \\
\hline C. rhizophorae & $24.8 \pm 0.7$ & $41.3 \pm 4.8$ & 3.5 & 5.5 & 28 & PE & [21] \\
\hline C. rhizophorae & $24.8 \pm 0.6$ & $39.0 \pm 5.0$ & 3.5 & 4.7 & $\sim 31$ & PE & [21] \\
\hline C. rhizophorae & $24.8 \pm 0.4$ & $38.4 \pm 4.2$ & 3.5 & 4.5 & $\sim 24$ & PE & [21] \\
\hline C. rhizophorae & $\sim 40$ & $\sim 80$ & 7 & $\sim 6.6$ & ** & $\mathrm{AL}$ & [39] \\
\hline C. rhizophorae & $46.5 \pm 3.4$ & $54.76 \pm 2.7$ & 1 & 6 & $\sim 83$ & BA & [12] \\
\hline C. rhizophorae & $46.0 \pm 3.8$ & $53.1 \pm 2.7$ & 1 & 5.1 & $\sim 83$ & BA & [12] \\
\hline Crassostrea sp. & $\sim 10$ & 60 & 5 & 9.9 & $\sim 93$ & SC & [10] \\
\hline Crassostrea sp. & $64.1 \pm 1.7$ & $65.1 \pm 1.7$ & 8 & $\star *$ & $\sim 88$ & PR & [14] \\
\hline Crassostrea sp. & $64.5 \pm 1.8$ & $66.0 \pm 1.7$ & 8 & ** & $\sim 88$ & PR & [14] \\
\hline Crassostrea sp. & $64.3 \pm 1.8$ & $65.5 \pm 1.7$ & 8 & ** & $\sim 87$ & PR & [14] \\
\hline Crassostrea sp. & $64.1 \pm 1.8$ & $65.6 \pm 1.8$ & 8 & ** & $\sim 89$ & PR & [14] \\
\hline
\end{tabular}

Table 3. Growth performance of oysters reaching commercial size. Species Commercial Cultivation period Species size (months)

State

$60 \mathrm{~mm}$
$60 \mathrm{~mm}$
$50 \mathrm{~mm}$
$70 \mathrm{~mm}$
$50 \mathrm{~mm}$
$70 \mathrm{~mm}$
$50 \mathrm{~mm}$
$70 \mathrm{~mm}$
$60 \mathrm{~mm}$
$50 \mathrm{~mm}$

7
4
9
18
19.5
18
14
7
5
18

PA
PA
SC
SC
SP
SC
SP
SC
SP
SC

\section{Source}

Present study
Present study
$[24]$
$[40]$
$[23]$
$[40]$
$[34]$
$[13]$
$[41]$
$[10]$


According to Gosling [42], several factors are related to the growth of bivalve mollusks, however the synergy between them makes it difficult to estimate the effect of an isolated factor. Pereira [20] cite that oyster growth and survival rates are directly influenced by biotic and abiotic factors (e.g., salinity, tidal amplitude, primary production, cropping systems). This assertion is corroborated by several authors $[6,10,13,21,22,35,37,39]$.

For a precise estimation of the growth rates of the cultured oyster in a tropic climatic area, Chagas and Herrmann [43] recommend a marking-recapture experiment, using the in situ fluorescent labeling method (the calcein solution base) and sizes. This method is effective because it presents excellent markers and does not negatively influence the survival of tagged individuals [43-47].

\section{CONCLUSION}

The variability in the growth rates of the Crassotrea tulipa oysters in the first months of the crop evidences a stress to the environmental conditions. However, from the minimization of this stress (occurring in the third month of cultivation), the equilibrium of the growth rates occurs. It is concluded, through the statistical analysis, that there is no difference between oyster growth rates at the end of the experiment, however, there are differences in total and percentage growth rates, especially oysters classified by juveniles and seeds, respectively. The salinity influenced only the growth of juvenile oysters, mainly because these oysters presented the highest monthly growth rates in the months where it showed the highest salinity values. The survival rates of oysters in this study were satisfactory and correlated to those found in other studies in the Brazilian coast.

In this study, the period of oyster cultivation to reach commercial size was shorter (four to seven months) than in other regions (e.g., south and southeast), even when compared to the same species.

Funding: To the National Council for Scientific and Technological Development (CNPq), for granting scholarships to carry out this research.

Acknowledgments: The authors thank the "Associação dos Agricultores, Pecuaristas e Aquicultores - ASAPAQ" of the Vila de Santo Antônio de Urindeua for the support to the development of the research. In particular the oyster farming: Dona Maria (current president), Tito, Miro and his Antônio (former president). The Federal Rural University of Amazon (UFRA), especially to the Socioenvironmental and Water Resources Institute (ISARH/UFRA), for the logistical support in the assignment of transportation to the authors' displacement to the research site.

Conflicts of Interest: The authors declare no conflict of interest.

\section{REFERENCES}

1. FAO. Fishery and Aquaculture Statistics. Rome: FAO; 2016.

2. Montanhini-Neto R, Ostrensky A. Revisão: Uso de modelos matemáticos para avaliação da influência de variáveis ambientais sobre o desenvolvimento de ostras no Brasil. PUBVET. 2012;6(4):1-33.

3. Ostrensky A, Borghetti JR, Soto D. Aqüicultura no Brasil: o desafio é crescer. Brasília: FAO; 2008.

4. Legat AP, Oliveira JAd, Lazoski CVS, Sole-Cava AM, Melo CMR, Galvéz AO. Caracterização genética de ostras nativas do gênero Crassostrea no Brasil: base para o estabelecimento de um programa nacional de melhoramento. Teresina: Embrapa Meio-Norte; 2009.

5. Sampaio DS, Tagliaro $\mathrm{CH}$, Schneider H, Beasley CR. Oyster culture on the Amazon mangrove coast: asymmetries and advances in an emerging sector. Rev Aquac. 2017;11(1):88-104.

6. Legat JFA, Puchnick-Legat A, Fogaça FHdS, Tureck CR, Suhnel S, Melo CMRd. Growth and survival of bottom oyster Crassostrea gasar cultured in the northeast and south of Brazil. B. Inst. Pesca. 2017;43(2):172-84.

7. Chagas RA. Biofouling no cultivo da ostra-do-mangue Crassostrea rhizophorae (Guilding, 1828) (Bivalvia: Ostreidae) em um estuário amazônico. Belém, PA: Universidade Federal Rural da Amazônia; 2016.

8. Melo MAD, Silva ARB, Beasley CR, Tagliaro CH. Multiplex species-specific PCR identification of native and nonnative oysters (Crassostrea) in Brazil: a useful tool for application in oyster culture and stock management. Aquac Int. 2013;21(6):1325-32.

9. Macedo ARG, Silva FL, Ribeiro SCA, Torres MF, Silva FNL, Medeiros LR. Perfil da ostreicultura na comunidade de Santo Antônio do Urindeua, Salinópolis, nordeste do Pará/Brasil. R Obs econ latinoam. 2016; Mar.

10. Maccacchero GB, Ferreira JF, Guzenski J. Influence of stocking density and culture management on growth and mortality of the mangrove native oyster Crassostrea sp. in southern Brazil. Biotemas. 2007;20(3):47-53.

11. IBGE. Produção da pecuária municipal 2016. Rio de Janeiro: IBGE; 2017.

12. Azevedo RV, Tonini WCT, Santos MJM, Braga LGT. Biofiltration, growth and body composition of oyster Crassostrea rhizophorae in effluents from shrimp Litopenaeus vannamei. Rev Ciênc Agron. 2015;46(1):193-203. 
13. Manzoni GC, Schimitt JF. Capitulo 17: Cultivo de ostras japonesas Crassostrea gigas (Mollusca: Bivalvia), na Armação do Itapocoroy, Penha, SC. Bases ecológicas para um desenvolvimento sustentável: estudos de caso em Penha, SC. Penha. p. 245-52.

14. Pinto FMVS. Efeito de organismos incrustantes sobre o crescimento e a sobrevivência de ostras nativas do gênero Crassostrea em um cultivo suspenso na Baía de Guaratuba (Paraná - Brasil). Pontal do Paraná: Universidade Federal do Paraná; 2007.

15. Pereira OM, Galvão MSN, Tanji S. Época e método de seleção de sementes de ostra Crassostrea brasiliana (Lamarck, 1819) no complexo estuarino - Laugna de Cananéia, estado de São Paulo (25오; 048ํW). B. Inst. Pesca. 1991;18(único):41-9.

16. Alvarenga L, Nalesso RC. Preliminary assessment of the potential for mangrove oyster cultivation in Piraquê-açu River Estuary (Aracruz, ES). Braz Arch Biol Technol. 2006;49(1):163-9.

17. Chagas RA, Barros MRF, Santos WCR, Herrmann M. Composition of the biofouling community associated with oyster culture in an Amazon estuary, Para state, Northern Brazil. Rev Biol Mar Oceanogr. 2018; 53(1):9-17.

18. Oliveira LFS, Ferreira MAP, Juen L, Nunes ZMP, Pantoja JCD, Paixão LF, Lima MNB, Rocha RM. Influence of the proximity to the ocean and seasonality on the growth performance of farmed mangrove oysters (Crassostrea gasar) in tropical environments. Aquaculture. 2018;496:661-7.

19. Vale AVP, Santos WCR, Barros MRF, Chagas RA, Herrmann M. Comparação de substratos artificiais na redução de bioincrustantes em um cultivo de ostras no estuário amazônico. Revista CEPSUL. 2020; 9(e2020001):1-16.

20. Pereira OM, Machado IC, Henriques MB, Yamanaka N. Crescimento da ostra Crassostrea brasiliana semeada sobre tabuleiro em diferentes densidades na região estuarino-lagunar de Cananéia-SP $\left(25^{\circ} \mathrm{s}, 48^{\circ} \mathrm{w}\right)$. B. Inst. Pesca. $2001 ; 27(2): 163-74$.

21. Cardoso Júnior LO, Lavander HD, Silva Neto SR, Souza AB, Silva LOB, Gálvez AO. Crescimento da ostra Crassostrea rhizophorae cultivada em diferentes densidades de estocagem no Litoral Norte de Pernambuco. Pesq Agropec Pernamb. 2012;17(único):10-4.

22. Rosa LC. Crescimento e sobrevivência da ostra Crassostrea brasiliana (Lamarck, 1819) mantida em um viveiro de cultivo de camarão. Arq Ciên Mar. 2014;47(1):64-8.

23. Pereira OM, Henriques MB, Machado IC. Estimativa da curva de crescimento da ostra Crassostrea brasiliana em bosques de mangue e proposta para sua extração ordenada no estuário de Cananéia, SP, Brasil. B. Inst. Pesca. 2003;29(1):19-28.

24. Lopes GR, Gomes CHAM, Tureck CR, Melo CMR. Growth of Crassostrea gasar cultured in marine and estuary environments in Brazilian waters. Pesq Agropec Bras. 2013;48(7):975-82.

25. Chagas RA, Herrmann M. Indução a desova de Crassostrea rhizophorae (Guilding, 1828) (Bivalvia: Ostreidae) através de métodos físico-químicos em condições controladas. Acta Fish Aquat Res. 2015;3(2):24-30.

26. Chagas RA, Silva REO, Passos TAF, Assis AS, Abreu VS, Santos WCR, Barros MRF, Herrmann M. Análise biomorfométrica da ostra-do-mangue cultivada no litoral amazônico. Scientia Plena. 2019;15(10):1-13.

27. Quayle DB. Pacific oyster culture in British Columbia. Canadian Bulletin of Fisheries and Aquatic Sciences 218. 1988.

28. Hopkins WG. Correlation coefficient: a new view of statistics 2000. Available from: http://www.sportsci.org/resource/stats/correl.html.

29. Zar JH. Biostatistical Analysis. 5th ed. New Jersey: Prentice Hall; 2010.

30. Hammer Ø. PAST - Palaeontological statistics. Version 4.0. Natural History Museum: University of Oslo. 2020.

31. Miranda RG, Pereira SdFP, Alves DTV, Oliveira GRF. Qualidade dos recursos hídricos da Amazônia - Rio Tapajós: avaliação de caso em relação aos elementos químicos e parâmetros físico-químico. Ambi-Agua. 2009;4(2):75-92.

32. Chagas RA, Abreu VS, Silva REO, Assis AS, Passos TAF, Barros MRF, Santos WCR, Herrmann M. Morphometric data of Crassostrea tulipa cultivated on the Amazonian coast. PANGAEA - Data Publisher for Earth \& Environmental Science. 2018. Available from: https://doi.pangaea.de/10.1594/PANGAEA.890779

33. Chagas RA, Herrmann M. Relative growth of Crassostrea spp. oysters on the Brazilian coast: A review. PANGAEAData Publisher for Earth \& Environmental Science. 2018. Available from: https://doi.pangaea.de/10.1594/PANGAEA.890027.

34. Pereira OM, Chagas Soares F. Análise da criação de ostra Crassostrea brasiliana (Lamarck, 1819), no sítio Guarapari, na região lagunar-estuarina de Cananéia-SP. B Inst Pesca. 1996;23(único):135-42.

35. Oliveira NL. Avaliação do crescimento da ostra nativa Crassostrea (Sacco, 1897) cultivada em estruturas de sistemas fixos nas localidades de Ponta Grossa (município de Vera Cruz) e lguape (município de Cachoeira), região do Recôncavo, na Baía de Todos os Santos, Bahia. Cruz das Almas: Universidade Federal do Recôncavo da Bahia; 2014. 
36. Pereira OM, Akaboshi S, Chagas Soares F. Cultivo experimental de Crassostrea brasiliana (Lamarck, 1819) no canal da Bertioga, São Paulo, Brasil (2354'30"S, 45¹3'42"W). B Inst Pesca. 1988;15(1):55-65.

37. Maccacchero GB, Guzenski J, Ferreira JF. Allometric growth on mangrove oyster Crassostrea rhizophorae (Guilding, 1828), cultured in Southern Brazil. Rev Cienc Agron. 2005;36(3):400-3.

38. Modesto GA, Maia EP, Olivera A, Brito LO. Utilização de Crassostrea rhizophorae (Guilding 1828) no tratamento dos efluentes do cultivo de Litopenaeus vannamei (Boone 1931). PanamJAS. 2010; 5(3):367-75.

39. Vilar TC. Crescimento da ostra-do-mangue Crassostrea rhizophorae (Guilding, 1828) cultivada em Barra de São Miguel, Alagoas, Brasil. Recife - PE: Universidade Federal de Pernambuco; 2012.

40. Nascimento IA. Crassostrea rhizophorae (Guilding) and C. brasiliana (Lamarck) in South and Central America. In: Menzel W, editor. Estuarine and marine bivalve mollusk culture. Boston: CRC Press; 1991. p. 125-34.

41. Akaboshi S. Notas sobre o comportamento da ostra japonesa, Crassostrea gigas (Thunberg, 1795), no litoral do estado do São Paulo, Brasil. B Inst Pesca. 1979; 6(único):93-104.

42. Gosling E. Marine Bivalve Molluscs. 2 nd. ed: John Wiley \& Sons, 2015.

43. Chagas RA, Herrmann M. Estimativas de crescimento de bivalves tropicais e subtropicais: recomendação para um método padronizado. Acta Fish Aquat Res. 2016; 4(2):28-38.

44. Herrmann M, Carstensen D, Fischer S, Laudien J, Penchaszadeh PE, Arntz WE. Population structure, growth and production of the wedge clam Donax hanleyanus (Bivalvia: Donacidae) from northern Argentinean beaches. J Shellfish Res. 2009; 28(3):511-26.

45. Herrmann M, Lepore ML, Laudien J, Arntz WE, Penchaszadeh PE. Growth estimations of the Argentinean wedge clam Donax hanleyanus: A comparison between length-frequency distribution and size-increment analysis. J Exp Mar Biol Ecol. 2009; 379(1-2):8-15.

46. Lepore ML, Penchaszadeh PE, Alfaya JEF, Herrmann M. Aplicación de calceína para la estimación del crecimiento de la almeja amarilla Mesodesma mactroides Reeve, 1854. Rev Biol Mar Oceanogr. 2009;44(3):767-74.

47. Herrmann M. A aptidão de calceína como mrcador de crescimento in situ nas ostras cultivadas e nativas em regiões subtropicais e tropicais do Brasil. In: Souza RAL (org.). Ecossistemas aquáticos: Tópicos especiais. Belém: Edufra; 2018. p. 239-46.

(C) 2021 by the authors. Submitted for possible open access publication under the terms and conditions of the Creative Commons Attribution (CC BY NC) license (https://creativecommons.org/licenses/by-nc/4.0/). 